\title{
Water Quality Assessment for Drinking and Irrigation Purpose of Rewa Block, District-Rewa, Madhya Pradesh, India
}

\author{
Satish Kumar Singh ${ }^{1 *}$, S. K. Tripathi ${ }^{2}$, K. P. Mishra ${ }^{1}$, A. K. Pandya ${ }^{1}$ and M. K. Awasthi ${ }^{3}$ \\ ${ }^{1}$ Faculty of Engineering and technology, MGCGVV, Chitrakoot Satna (MP), India \\ ${ }^{2}$ Department of Science, MGCGVV, Chitrakoot Satna (MP), India \\ ${ }^{3}$ Department of Soil and Water Engineering, CAE, JNKVV Jabalpur (MP), India \\ *Corresponding author
}

\begin{abstract}
A B S T R A C T
\section{Keywords}

Groundwater Quality, Rewa block, Rewa, Madhya Pradesh, India

Article Info

Accepted:

22 March 2020

Available Online:

10 April 2020

This study, deals with groundwater quality for Drinking and Irrigation purpose of Rewa Block, Ditrict-Rewa, Madhya Pradesh, India. Study area covers an area of $704.17 \mathrm{~km}^{2}$ and lies between $81^{\circ} 06^{\prime} 00^{\prime \prime}$ and $81^{\circ} 30^{\prime} 00^{\prime \prime}$ E longitudes and $24^{\circ} 18^{\prime} 00^{\prime \prime}$ and $24^{\circ} 42^{\prime} 00^{\prime \prime} \mathrm{N}$ latitudes. Geologically, the area is occupied by sandstone and shale of Rewa Group belonging to Vindhyan super-group. The groundwater occurs in semi-confined to confined condition. A total number of fifty ground water samples were collected in pre and post-monsoon seasons of 2018-19 from different locations of the study area and analyzed for comically analysis for various water quality parameters such as $\mathrm{PH}$, electrical conductivity (EC), Total dissolved solids (TDS), Total hardness (TH), chloride (Cl), carbonate, bicarbonate, sodium $(\mathrm{Na})$, Potassium $(\mathrm{K})$ and calcium with magnesium $(\mathrm{Ca}+\mathrm{Mg})$. On comparing the results against water quality standards laid by World Health Organization (WHO) and BIS. It is observed that some parameters exceed the standard limits. The ground water is hard to very hard in nature. The overall study reveals that water concentration of various cations and anions suggest that the groundwater of the area is partially suitable for drinking purpose. To overall irrigation water quality of the samples collected, some computed water quality parameters have been considered. The analysis of various parameters like EC, sodium percentage, integrated sodium adsorption ratio (SAR), Soluble Sodium Percentage (SSP), Permeability Index (PI) and Residual Sodium Carbonate (RSC) suggest that ground water of the area is suitable for irrigation purpose.
\end{abstract}

\section{Introduction}

Ground water has been used as major sources of drinking water in both rural and urban areas in the world. In India alone, nearly $80 \%$ of the rural population depends on untreated ground water. The quality of ground water in the various part of our country has been studied by various workers. Polluted water is responsible for spread of various water borne diseases. Therefore in present study an attempt has been made to evaluate the physiochemical characteristics of ground water for drinking and irrigation purpose of Rewa block, Rewa district Madhya Pradesh, India.

Fresh water is the most precious material for survival on earth, not only human life but also for flora and fauna. Groundwater quality is 
one of the most important aspects in water resource studies (Ackah et al., 2011; Sayyed and Wagh, 2011). It is largely controlled by discharge recharge, nature of the host and associated rocks as well as contaminated activities (Raghunath, 1987; Sayyed and Sayadi, 2011; zhang et al., 2011). Only 2 to $3 \%$ total water on earth is fresh water. Water pollution is classified into four classes likewise-physical, chemical, biological and physiological pollution of water. Physical water pollution brings about changes in water with regard to its color, density, test, turbidity and thermal properties etc. the chemical pollution of water causes changes in acidity and alkalinity/pH. Biological pollution is caused by bacteria, alge, virus, protozoa etc. physiological pollution of water by caused by several chemical agents such as chlorine, sulphur dioxide, hydrogen sulphide ketones, phenols amines etc. according to WHO organization, about $80 \%$ of all the disease in human.

The quality of groundwater is affected by many factors such as physic-chemical characteristics of soil, weathering of rocks, and rainfall etc. (Pureshotham et al., 2011). Groundwater quality assessment of different quality parameters has been carried out by various researches (Hegde, 2006; Pandian and Shankar, 2007; Popleare and Dewalkar, 2007; Mishra, 2010). The groundwater quality assessment for drinking and irrigation purpose in the Vindhyan region has carried out by few researchers (Tiwari et al., 2009, 2010; Mishra et al., 2012).

\section{About study area}

Study area covers an area of $704.17 \mathrm{~km}^{2}$ and lies between $81^{\circ} 06^{\prime} 00^{\prime \prime}$ and $81^{\circ} 30^{\prime} 00^{\prime \prime} \mathrm{E}$ longitudes and $24^{\circ} 18^{\prime} 00^{\prime}$ ' and $24^{\circ} 42^{\prime} 00^{\prime \prime} \mathrm{N}$ latitudes. Geologically, the area is occupied by sandstone and shale of Rewa Group belonging to Vindhyan super-group. The groundwater occurs in semi-confined to confined condition. A total number of fifty ground water samples were collected in the study area. Location map of the study area is shown in Figure 1; The Rewa block is bounded on the north by Semaria block and Raipur Krachulian block, on the east and southeast by Sidhi district, and on the west by Satna district.

\section{Materials and Methods}

Ground water samples were collected from hand pups/dug well and surface water (River/pond) of the different locations of the study area during pre and post monsoon seasons of year 2018. The sample was collected in plastic bottles of $500 \mathrm{ml}$ capacity. The sampling bottles were thoroughly washed with 1:1 Nitric acid $\left(\mathrm{HNO}_{3}\right)$ and then cleaned and rinsed with distilled water. At the sampling site bottles were rinsed two to three times with water samples to be examined finally filling with it (Sankar Prashad Mishra, 2016). During sampling from a hand pump the water was pumped to waste for about four to five minutes and then sample was collected directly from a hand pump. The entire samples were collected from ten to fifty meter depth and lifted water through hand pump.

All samples were labelled and write the GPS location latitude and longitude also mansion. Samples store were brought to laboratory and refrigerated at $4^{\circ} \mathrm{C}$. The physicochemical analysis was done using procedure of standard methods. The methods used for determination of various physicochemical parameters are given Table 1.

\section{Quality of groundwater for irrigation}

The suitability of groundwater for irrigation is determined on the basis of physical, chemical and bacteriological characteristics (Table 2). The criteria for suitability of groundwater for 
irrigation are based on Total Dissolved Solids (TDS), Electrical Conductivity (EC), Sodium Salts and bicarbonate concentration (Richards, 1954; Todd, 1980; Eatson, 1950; Davis and Dewiest, 1966; Singh, 2002).

To assess the overall irrigational water quality of the samples collected, five to six computed water quality parameters have been considered; namely - Sodium Adsorption Ratio (SAR), Residual Sodium Carbonate (RSC), Permeability Index (P.I.), Soluble Sodium Percentage (SSP), Magnesium Adsorption Ratio (MAR) and Kelly's Ratio.

\section{Electrical conductivity}

Electrical conductivity is a function of temperature, type and concentration of various ions. Classification of irrigation water based on electrical conductivity is presented in Table 3. A solution offers some resistance to the passage of electric current through it depending on the concentration and type of ions present. Higher the salt contents lesser the resistance to the flow of current. The resistance(R) is defined by Ohm's law as the ration of electrical potential in volt (E) and strength of current in ampere (I).

$\frac{E}{I}=\frac{\text { Volts }}{\text { Curent }}=R$ in Ohm

Electrical conductivity of conductance is the reciprocal of resistance.

$1 / \mathrm{R}=1 / \mathrm{ohm}=\mathrm{mhos} \quad$ (reverse of ohm) (at present $\mathrm{mmhos} / \mathrm{cm}$ is expressed in terms of $\mathrm{dS} / \mathrm{m})$.

\section{Sodium}

If the proportion of sodium is high in groundwater for irrigation purpose, it can destroy soil structure (Table 4). A simple method for evaluating the changes of high- sodium is the Sodium Adsorption Ratio (SAR) and the sodium percentage (soluble sodium percentage, SSP) is calculated as follows:

$S A R=N a^{+} / \sqrt{\frac{C a^{++}+\mathrm{Mg}^{2++}}{2}}$

$N A \%=\frac{N a^{+}+K^{+}}{C a^{++}+M g^{++}+N a^{+}+K^{+}} * 100$

\section{Residual sodium carbonate (RSC)}

Irrigation water with high RSC 8,9 is considered to be deleterious to the physical properties of the soil. More RSC may reduce permeability of soils and tendency of fixing the sodium in soils (Table 4). The residual sodium carbonate is calculated using the following equation:

$\mathrm{RSC}(\mathrm{meq} / \mathrm{l})=\left(\mathrm{HCO}_{3}{ }^{-}+\mathrm{CO}_{3}^{-}\right)-\left(\mathrm{Ca}^{++}+\right.$ $\left.\mathrm{Mg}^{++}\right)$

\section{Permeability index (PI)}

Another modified criterion has evolved based on the solubility of salts and the reaction occurring in the soil solution from caution exchange for estimating the quality of agricultural waters (Gupta SK, Gupta, IC, 1987). Soil permeability is affected by longterm use of irrigation water and is influenced by - (a) Total dissolved solids, (b) sodium contents, (c) bicarbonate content.

To incorporate the first three items Doreen had empirically developed a term called, 'Permeability Index' after conducting a series of experiments for which he had used a large number of irrigation waters varying in ionic relationships and concentration (Doneen, 1964). PI is classified under Class I (>75\% permeability), Class II (25-75\% permeability) and Class III ( $<75 \%$ permeability) orders. 
The permeability index is given by the following formula:

$$
P I=\frac{\mathrm{Na}^{+}+\sqrt{\left(\mathrm{HCO}^{-}\right)}}{\left(\mathrm{Ca}^{++}+\mathrm{Mg}^{++}+\mathrm{Na}^{+}\right)} * 100
$$

Where, the ions are expressed in meq/l.

\section{Soluble sodium percentage (SSP)}

High sodium ion concentration in soil can take a toll on internal drainage patterns in soil as release of calcium and magnesium ions are facilitated due to absorption of sodium by clay particles. SSP categorizes water into two broad classes - water having SSP $<=200$ is considered suitable for irrigation whereas water with SSP > 200 is considered unsuitable for irrigation water. Soluble sodium percentage (SSP) was calculated using the following equation:

$$
S S P=\frac{\left(\mathrm{Na}^{+}+\mathrm{K}^{+}\right)}{\left(\mathrm{Ca}^{++}+\mathrm{Mg}^{++}+\mathrm{Na}^{+}+\mathrm{K}^{+}\right)} * 100
$$

Where, concentrations of all ions have been expressed in meq/l.

\section{Kelly's ratio (KR)}

Kelly's Ratio was devised by Kelly and is measured considering sodium ion concentration against calcium and magnesium ion concentrations (Kelly WP 1940). Waters with a KI value $<1$ is considered suitable for irrigation, while those with greater ratios are rendered unsuitable. Kelly's Ratio is calculated using the formula:

$K R=\frac{N a^{++}}{\left(C a^{++}+M g^{++}\right)}$

Where, concentrations of all ions have been expressed in meq/l.

\section{Results and Discussion}

\section{Water quality for irrigation purposes}

To assess the overall irrigational water quality of the samples collected, six computed water quality parameters have been considered; namely- Sodium Adsorption Ratio (SAR), Soluble Sodium Percentage (SSP), Permeability Index (PI), Residual Sodium Carbonate (RSC), Kelly's Ratio and Magnesium Adsorption Ratio (MAR).

\section{Sodium adsorption ratio (SAR)}

Sodium adsorption ratio is a measure of the sodality of the soil determined through quantitative chemical analysis of water in contact with it. An excess of $\mathrm{HCO}_{3}$ and $\mathrm{CO}_{3}{ }^{--}$ ions in water react with $\mathrm{Na}^{+}$in soil, resulting in a sodium hazard. SAR values are plotted against EC values over the salinity diagram to categorize analyzed water samples according to their irrigational suitable quotient. In the present study the SAR values range from 0.3 to $7.7 \mathrm{me} / \mathrm{l}$ in pre-monsoon and 0.3 to $2.8 \mathrm{me} / 1$ in post-monsoon. Based on the SAR values all samples have low sodium hazard and on plotting the salinity diagram (Fig. 2), the water sample fall in the $\mathrm{C} 2-\mathrm{S} 1$ and $\mathrm{C} 3-$ S1classes in pre-monsoon and $\mathrm{C} 2-\mathrm{S} 1$ and $\mathrm{C} 3-$ $\mathrm{S} 1$ classes in post-monsoon, and hence can be considered moderately and highly suitable for irrigation.

\section{Soluble sodium percentage (SSP)}

High sodium ion concentration in soil can take a toll on internal drainage patterns in soil as release of calcium and magnesium ions are facilitated due to absorption of sodium by clay particles. The SSP values range from 4.8 to $79.6 \mathrm{me} / \mathrm{l}$ in pre-monsoon and 7.5 to 44.4 me/l during post-monsoon. Fig. 3, present the spatial distribution maps of SSP for pre-monsoon and pre-monsoon sessions respectively. 
The SSP values and EC values have been plotted on the Wilcox diagram (Wilcox L.V. 1955 ) and found to fall under the $80 \%$ sample very good to good, $33 \%$ good to permissible, $6 \%$ doubtful to unsuitable and $2 \%$ sample unsuitable water quality in pre-monsoon similarly $52 \%$ sample very good to good, $39 \%$ good to permissible and $6 \%, 2 \%$ sample doubtful to unsuitable and unsuitable water quality respectively in post-monsoon.

\section{Permeability index (PI)}

Another modified criterion has evolved based on the solubility of salts and the reaction occurring in the soil solution from cation exchange for estimating the quality of agricultural waters (Gupta S.K. 1987). Soil permeability is affected by ling-term use of irrigation water and is influenced by (a) Total dissolved solids, (b) sodium contents, (c) bicarbonate content. To incorporate the first three items. Doneen had empirically developed a term called, Permeability Index after conducting a series of experiments for which he had used a large number of irrigation waters varying in ionic relationships and concentration (Doneen, 1964). The permeability index varies from 8.44 to $99.89 \mathrm{me} / 1$ in pre-monsoon and from 10.25 it $59.77 \mathrm{me} / \mathrm{l}$ in post-monsoon season. Doneen's chart for pre and post-monsoon sessions have been presented in Fig. 4.

PI is classified under Class-I (>75\% permeability), Class-II (25-75\% permeability) and Class-III ( $<75 \%$ permeability) orders. Class-I and Class-II waters are categorized as good for irrigation and Class-III waters are unsuitable with $25 \%$ of maximum permeability.

\section{Residual sodium carbonate (RSC)}

The residual sodium carbonate index of water or soil signifies the alkalinity hazard posed by it and it finds the suitability of water for irrigation in case of clay soil. Residual sodium carbonate values should be preferably $<1.25$ to be rendered suitable for irrigational purposes and hence in the present study where RSC values variation range between -22.2 to 9.0 in pre-monsoon and -25.2 to 1.48 in postmonsoon season. More than $93 \%$ to $100 \%$ of the excellent water samples have $\mathrm{RSC}<2.5$ (Fig. 5); it can be concluded that water in this area poses a suitable irrigation water $93 \%$ sample in pre-monsoon period. In the Postmonsoon period though $100 \%$ sample of RSC values fall in the safe and excellent category, indicating localized hazard (Table 5).

\section{Kelly's ratio}

Kelly's Ratio was devised by Kelly and is measured considering sodium ion concentration against calcium and magnesium ion concentrations. Water with a KI value $<1$ are considered suitable for irrigation, while those with greater ratios are rendered unsuitable.

During pre-monsoon KR values vary between 0.16 to $8.44 \mathrm{me} / \mathrm{l}$, and post-monsoon and values vary between 0.24 to $1.72 \mathrm{me} / \mathrm{l}$. according to Kelly's ratio water analyzed is suitable for irrigation during pre-monsoon season of $80 \%$ sample and $78 \%$ sample in post-monsoon season.

\section{Magnesium adsorption ratio (MAR)}

MAR categorized water into two broad classes - water having MAR $<50$ is considered suitable for irrigation whereas water with MAR > 50 is considered unsuitable. Because MAR values should be preferably greater than 50 to be rendered unsuitable for irrigational purpose and hence in the present study where MAR values range vary between 51.33 to $93.28 \mathrm{me} / \mathrm{l}$ in premonsoon and 74.92 to $92.78 \mathrm{me} / \mathrm{l}$ in post- 
monsoon season. The MAR based on which it can be concluded that almost water samples are unsuitable classes for irrigation during both periods.

\section{Water quality for drinking purposes}

In the large and specially semi urban or rural parts of our country groundwater sources in form of fug wells of bore wells are the only source of drinking water standard, the total Hardness of samples have been measured and the use of Hydro geochemical facies (Piper diagram) and Water Quality Index have been make.

\section{Hydrogeochemical facies}

A Piper Trilinear diagram is a graphical representation classifying water based on the dominant presence of cations and anions and has widespread use to assess the water type. Piper diagram can predict the water type in three ways- fresh type, sulfate type and saline type.

In Figure 6-a, and 6-b it can be seen the water samples fall under $\mathrm{CaHCO}_{3}$ or the bicarbonate type during post-monsoon whereas during pre-monsoon groundwater in certain locations falls under the $\mathrm{Ca}-\mathrm{Mg}-\mathrm{Cl}-\mathrm{SO}_{4}$ types as well. Samples in the top quadrant are calcium sulphate waters, which are typical of gypsum ground water and mine drainage of pre and post monsoon season.

\section{Water quality index (WQI)}

Water quality index values depicted through the weighted arithmetic water quality index method were shown in Table 6 indicates range of WQI values according to which the five classes in pre and post monsoon. The pie charts presented in Fig. 7-a, and 7-b depiction clearly explains that the pre and post monsoon values are much suitable for drinking purpose in most of the station where water samples are collected. Whereas in very small sample shows that not suitability for drinking according to the Table 6 . The pollution before post monsoon is more than that of pre monsoon in current study.

\section{Gibb's diagram}

The Gibb's Diagram is prepared using TDS, $\mathrm{Na}^{+}, \mathrm{K}^{+}, \mathrm{Ca}^{+}, \mathrm{Cl}^{-}, \mathrm{SO}_{4}^{-}$and $\mathrm{CHO}^{-}$ concentrations in groundwater. The predominant samples fall in the rock-water interaction dominance and evaporation dominance field of the Gibbs diagram (Fig. 8$\mathrm{a}$ and 8-b). From these diagrams it can be interpreted that during both sampling sessions' rock- water interaction processes control the levels of all chemical constituents in groundwater of study area.

Table.1 Methods used for analysis of water quality parameters

\begin{tabular}{|r|l|l|}
\hline S. No. & \multicolumn{1}{|c|}{ Parameters } & \multicolumn{1}{|c|}{ Methods } \\
\hline $\mathbf{1}$ & $\mathrm{pH}$ & $\mathrm{pH}$ meter \\
\hline $\mathbf{2}$ & Electrical Conductivity & Conductivity meter \\
\hline $\mathbf{3}$ & Total Hardness & EDTA titration method \\
\hline $\mathbf{4}$ & total Dissolved Solid & Water quality analyser instrument \\
\hline $\mathbf{5}$ & Chloride & Argentometric titration method \\
\hline $\mathbf{6}$ & Calcium and Magnesium & Titration method \\
\hline $\mathbf{7}$ & Sodium, Calcium and Potassium & Flame photometer \\
\hline
\end{tabular}


Table.2 Standards of water quality by WHO and BIS for drinking purpose

\begin{tabular}{|c|l|c|c|c|c|}
\hline \multirow{2}{*}{$\begin{array}{c}\text { S. } \\
\text { No. }\end{array}$} & \multirow{2}{*}{$\begin{array}{c}\text { Water quality } \\
\text { parameters }\end{array}$} & \multicolumn{2}{|c|}{ WHO (1991) } & \multicolumn{2}{|c|}{ BIS(1991) } \\
\cline { 3 - 6 } & & $\begin{array}{c}\text { Max. } \\
\text { Desirable }\end{array}$ & $\begin{array}{c}\text { Max. } \\
\text { Permissible }\end{array}$ & $\begin{array}{c}\text { Max. } \\
\text { Desirable }\end{array}$ & $\begin{array}{c}\text { Max. } \\
\text { Permissible }\end{array}$ \\
\hline $\mathbf{1}$ & $\mathrm{pH}$ & 7 & 8.5 & 6.5 & 8.5 \\
\hline $\mathbf{2}$ & $\mathrm{EC}$ & - & 1400 & - & - \\
\hline $\mathbf{3}$ & $\mathrm{TH}(\mathrm{mg} / \mathrm{l})$ & 100 & 500 & 300 & 600 \\
\hline $\mathbf{4}$ & $\mathrm{TDS}(\mathrm{mg} / \mathrm{l})$ & 500 & 1500 & 500 & 1000 \\
\hline $\mathbf{5}$ & $\mathrm{Ca}(\mathrm{mg} / \mathrm{l})$ & 75 & 200 & 75 & 200 \\
\hline $\mathbf{6}$ & $\mathrm{Mg}(\mathrm{mg} / \mathrm{l})$ & 30 & 150 & 30 & 100 \\
\hline $\mathbf{7}$ & $\mathrm{Na}(\mathrm{mg} / \mathrm{l})$ & - & 200 & - & 200 \\
\hline $\mathbf{8}$ & $\mathrm{K}(\mathrm{mg} / \mathrm{l})$ & - & 12 & - & - \\
\hline $\mathbf{9}$ & $\mathrm{Cl}(\mathrm{mg} / \mathrm{l})$ & 200 & 600 & 250 & 1000 \\
\hline $\mathbf{1 0}$ & $\mathrm{SO} 4(\mathrm{mg} / \mathrm{l})$ & 200 & 400 & 150 & 400 \\
\hline $\mathbf{1 1}$ & F (mg/l)l & 1 & 1.5 & 1 & 1.5 \\
\hline $\mathbf{1 2}$ & Turbidity (NTU) & & & 1 & 5 \\
\hline
\end{tabular}

Table.3 Calcification of irrigation water based on electrical conductivity

\begin{tabular}{|c|c|c|c|}
\hline S. No. & Type of water & Classification & $\begin{array}{c}\text { Electrical } \\
\text { Conductivity }(\boldsymbol{\mu} / \mathbf{c m})\end{array}$ \\
\hline $\mathbf{1}$ & Low Sodium & Excellent & $100-250$ \\
\hline $\mathbf{2}$ & Medium & Good & $250-750$ \\
\hline $\mathbf{3}$ & Saline & Permissible & $750-2000$ \\
\hline $\mathbf{4}$ & Highly Saline & Doubtful & $2000-3000$ \\
\hline $\mathbf{5}$ & Very Highly Saline & Unsuitable & $>3000$ \\
\hline
\end{tabular}

Table.4 Classification of water based on Sodium Adsorption Ratio (SAR)

\begin{tabular}{|c|c|c|c|}
\hline S. No. & Type of water & Classification & SAR Value \\
\hline $\mathbf{1}$ & Low Sodium & Excellent & $<10$ \\
\hline $\mathbf{2}$ & Medium & Good & $10-18$ \\
\hline $\mathbf{3}$ & Highly Saline & Doubtful & $18-26$ \\
\hline $\mathbf{4}$ & Very Highly Saline & Unsuitable & $>26$ \\
\hline
\end{tabular}

Table.5 Calcification of water based in Residual Sodium Carbonate (RSC)

\begin{tabular}{|c|c|c|}
\hline S. No. & Class & RSC \\
\hline $\mathbf{1}$ & Excellent & $<1.25$ \\
\hline $\mathbf{2}$ & Good & $1.25-2.25$ \\
\hline $\mathbf{3}$ & Unsuitable & $>2.5$ \\
\hline
\end{tabular}


Table.6 Classification of samples according to standards specified for water quality index

\begin{tabular}{|c|c|c|c|c|c|c|}
\hline \multirow[t]{2}{*}{ Parameter } & \multirow[t]{2}{*}{ Range } & \multirow[t]{2}{*}{ Class } & \multicolumn{2}{|c|}{ No. of Sample } & \multicolumn{2}{|c|}{ \% of Sample } \\
\hline & & & $\begin{array}{c}\text { Pre- } \\
\text { monsoon }\end{array}$ & $\begin{array}{c}\text { Post- } \\
\text { monsoon }\end{array}$ & $\begin{array}{c}\text { Pre- } \\
\text { monsoon }\end{array}$ & $\begin{array}{c}\text { Post- } \\
\text { monsoon }\end{array}$ \\
\hline \multirow[t]{5}{*}{ SAR } & $<20$ & Excellent & 46 & 46 & 100 & 100 \\
\hline & $20-40$ & Good & 0 & 0 & 0 & 0 \\
\hline & $40-60$ & Permissible & 0 & 0 & 0 & 0 \\
\hline & $60-80$ & Doubtful & 0 & 0 & 0 & 0 \\
\hline & $>80$ & Unsafe & 0 & 0 & 0 & 0 \\
\hline \multirow{5}{*}{$\begin{array}{c}\text { EC WHO } \\
(2008)\end{array}$} & $<250$ & Excellent & 3 & 2 & 7 & 4 \\
\hline & $250-750$ & Good & 14 & 11 & 30 & 24 \\
\hline & $750-2000$ & Permissible & 25 & 29 & 54 & 63 \\
\hline & $2000-3000$ & Doubtful & 3 & 3 & 7 & 7 \\
\hline & $>3000$ & Unsafe & 1 & 1 & 2 & 2 \\
\hline \multirow{4}{*}{$\begin{array}{c}\text { TH } \\
\text { (Sawyer } \\
\& \\
\text { McCarty, } \\
\text { 1967) }\end{array}$} & $<75$ & Soft & 1 & 0 & 2 & 0 \\
\hline & $75-150$ & Moderate & 4 & 3 & 9 & 7 \\
\hline & $150-300$ & Hard & 6 & 5 & 13 & 11 \\
\hline & $>300$ & Very Hard & 35 & 38 & 76 & 83 \\
\hline \multirow[t]{3}{*}{ RSC } & $<1.25$ & Safe & 39 & 44 & 85 & 96 \\
\hline & $1.25-2.50$ & $\begin{array}{l}\text { Marginally } \\
\text { Suitable }\end{array}$ & 2 & 2 & 4 & 4 \\
\hline & $>2.50$ & Unsuitable & 5 & 0 & 11 & 0 \\
\hline \multirow[t]{2}{*}{ MAR } & $<50$ & Suitable & 0 & 0 & 0 & 0 \\
\hline & $>50$ & Unsuitable & 46 & 46 & 100 & 100 \\
\hline \multirow[t]{2}{*}{ SSP } & 200 & Suitable & 46 & 46 & 100 & 100 \\
\hline & $>200$ & Unsuitable & 0 & 0 & 0 & 0 \\
\hline \multirow[t]{2}{*}{$\mathbf{K R}$} & $<1.0$ & Suitable & 35 & 36 & 76 & 78 \\
\hline & $>1.0$ & Unsuitable & 11 & 10 & 24 & 22 \\
\hline \multirow[t]{3}{*}{$\mathbf{P I}$} & $<80$ & Good & 44 & 46 & 96 & 100 \\
\hline & $80-100$ & Moderate & 2 & 0 & 4 & 0 \\
\hline & $100-120$ & Poor & 0 & 0 & 0 & 0 \\
\hline \multirow[t]{5}{*}{ WQI } & $0-25$ & Excellent & 9 & 12 & 20 & 26 \\
\hline & $25-50$ & Good & 27 & 26 & 59 & 57 \\
\hline & $50-75$ & Poor & 6 & 4 & 13 & 9 \\
\hline & $75-100$ & Very Poor & 2 & 3 & 4 & 7 \\
\hline & $>100$ & $\begin{array}{l}\text { Unfit for } \\
\text { Drinking }\end{array}$ & 2 & 1 & 4 & 2 \\
\hline
\end{tabular}

Note: $\mathrm{SAR}=$ Sodium Adsorption Ratio, $\mathrm{SSP}=$ Soluble Sodium Percentage, $\mathrm{PI}=$ Permeability Index RSC $=$ Residual Sodium Carbonate, KR = Kelly's Ratio, All values meq/l. 

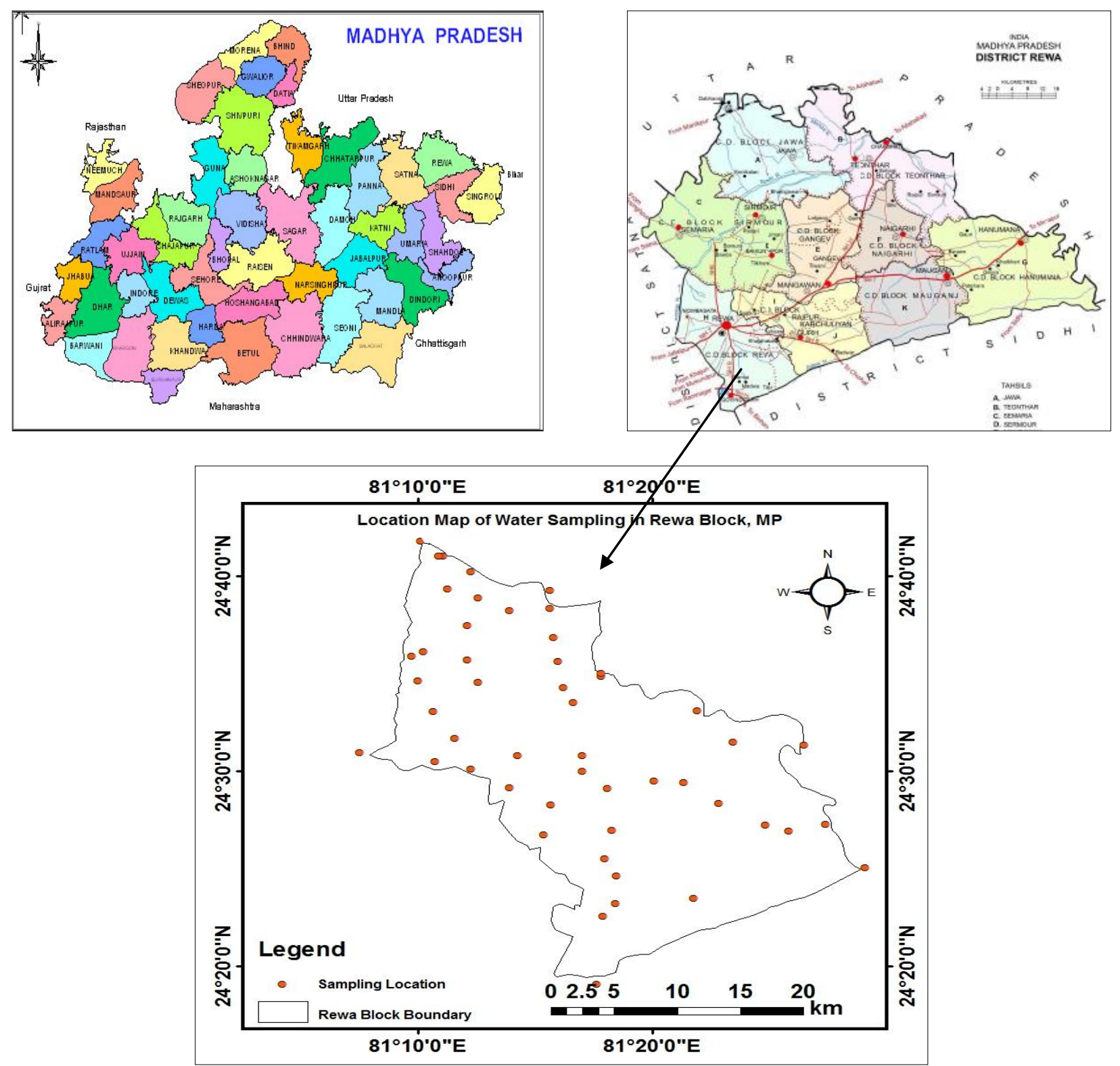

Fig.1 Location map of the water sampling points in the study area

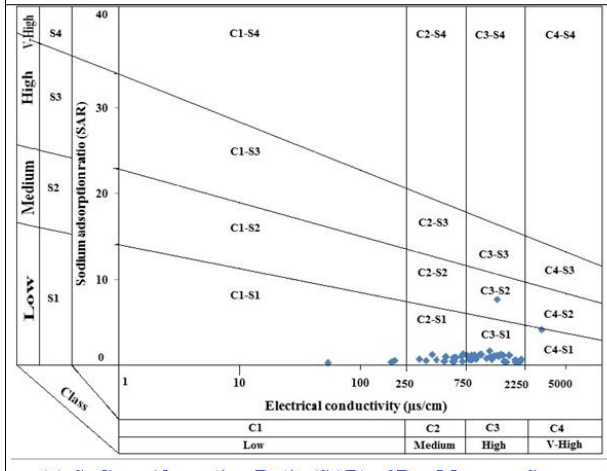

(a) Sodium Absorption Ratio (SAR) of Pre-Monsoon Season

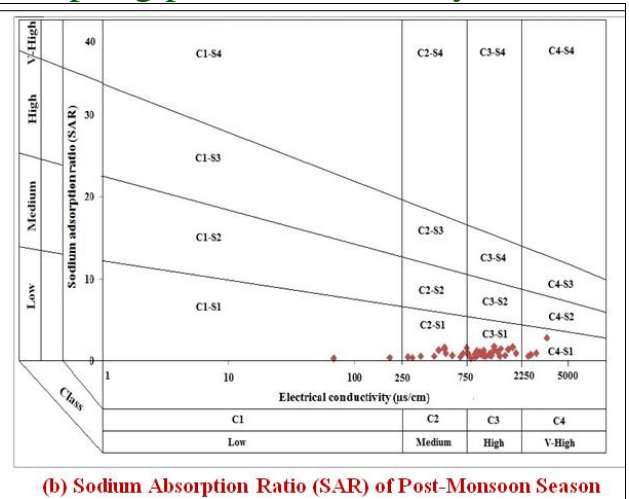

Fig.2 Salinity diagram of pre and post monsoon seasons 


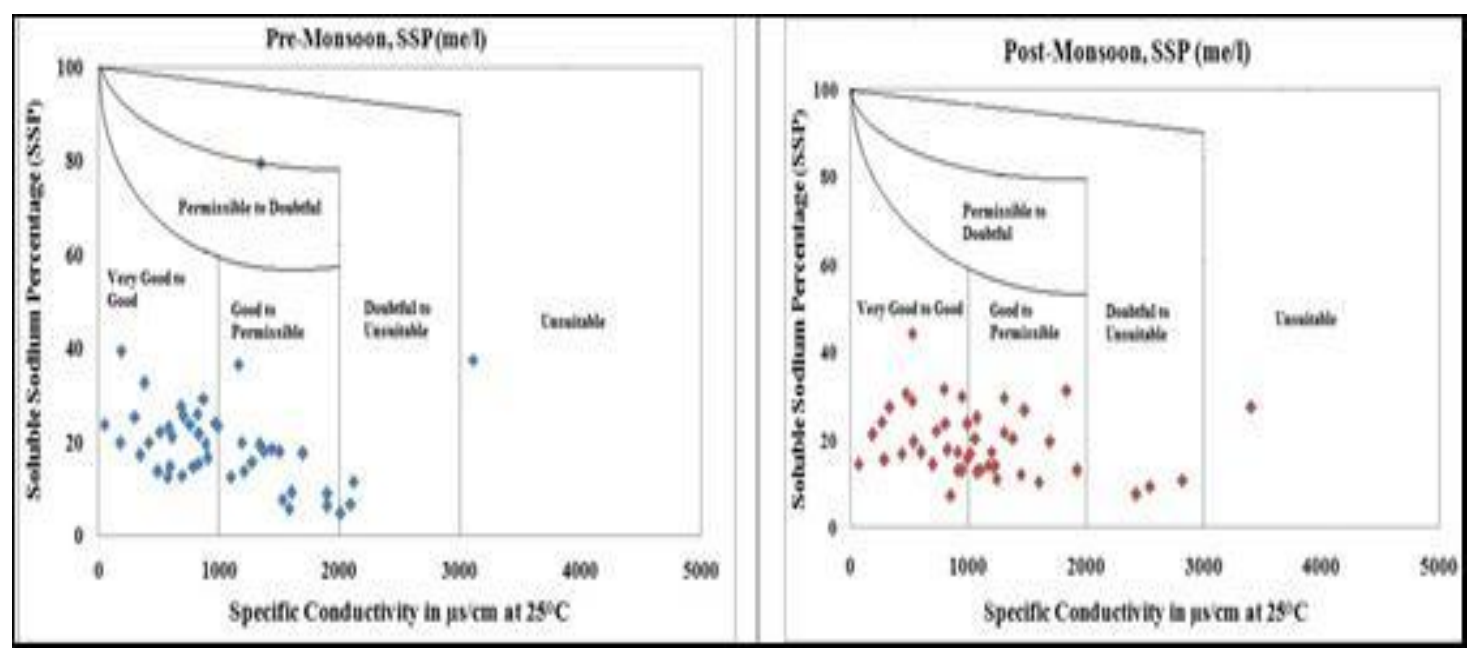

Fig.3 Wilcox diagram for pre and post monsoon seasons

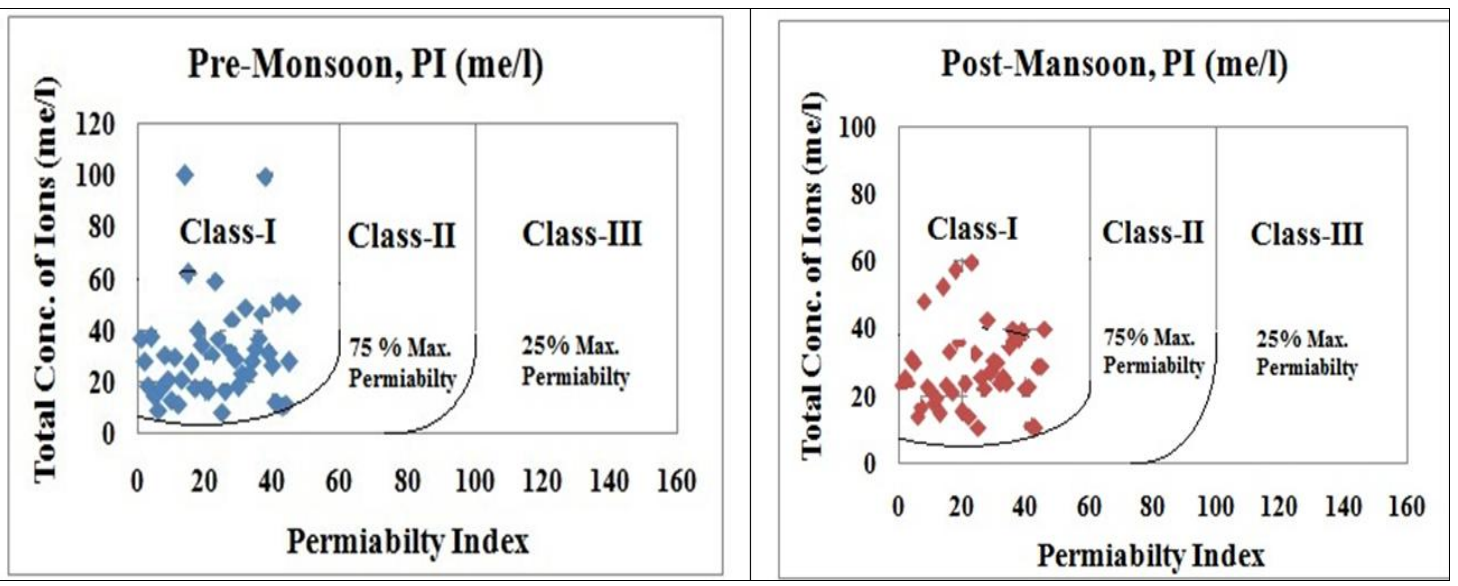

Fig.4 Doneen's chart for permeability index values of pre and post monsoon seasons

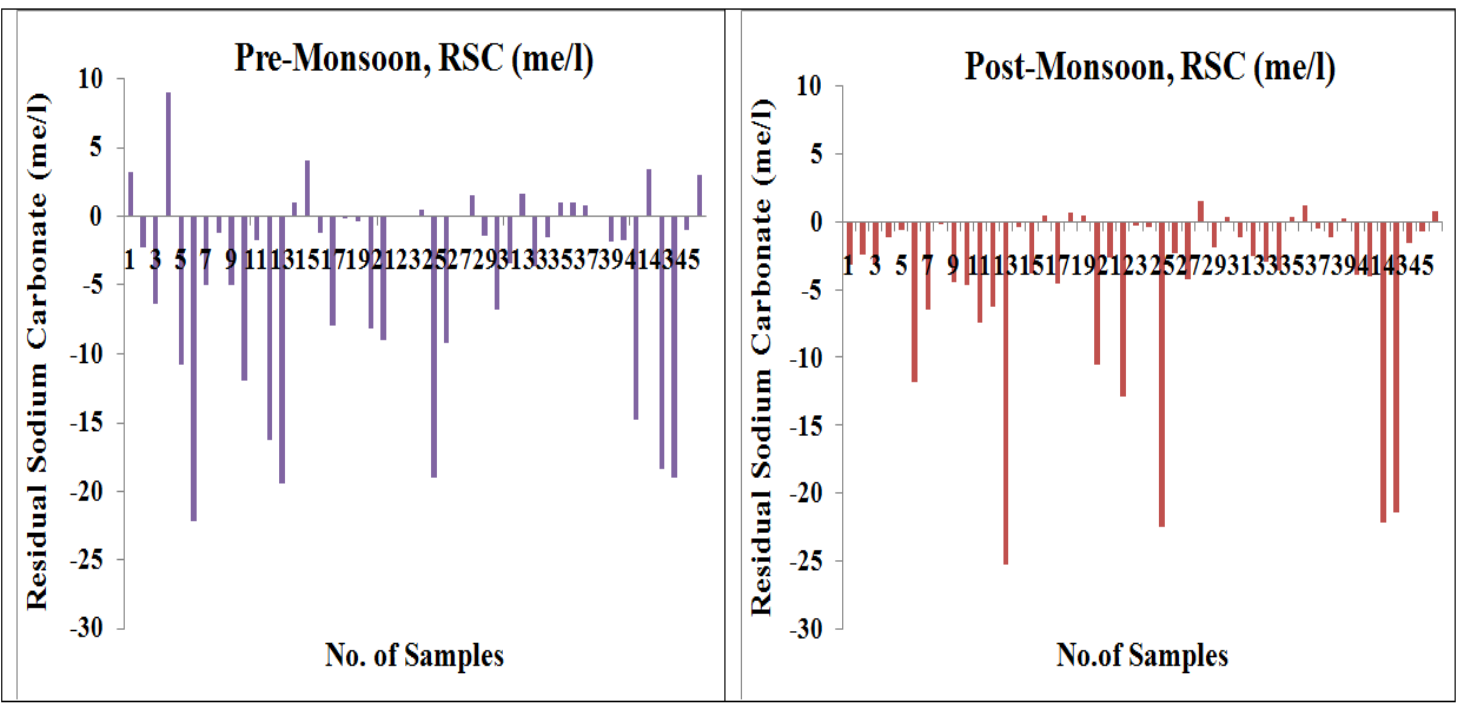

Fig.5 Special distribution of residual sodium carbonate (RSC) for pre and post monsoon seasons 


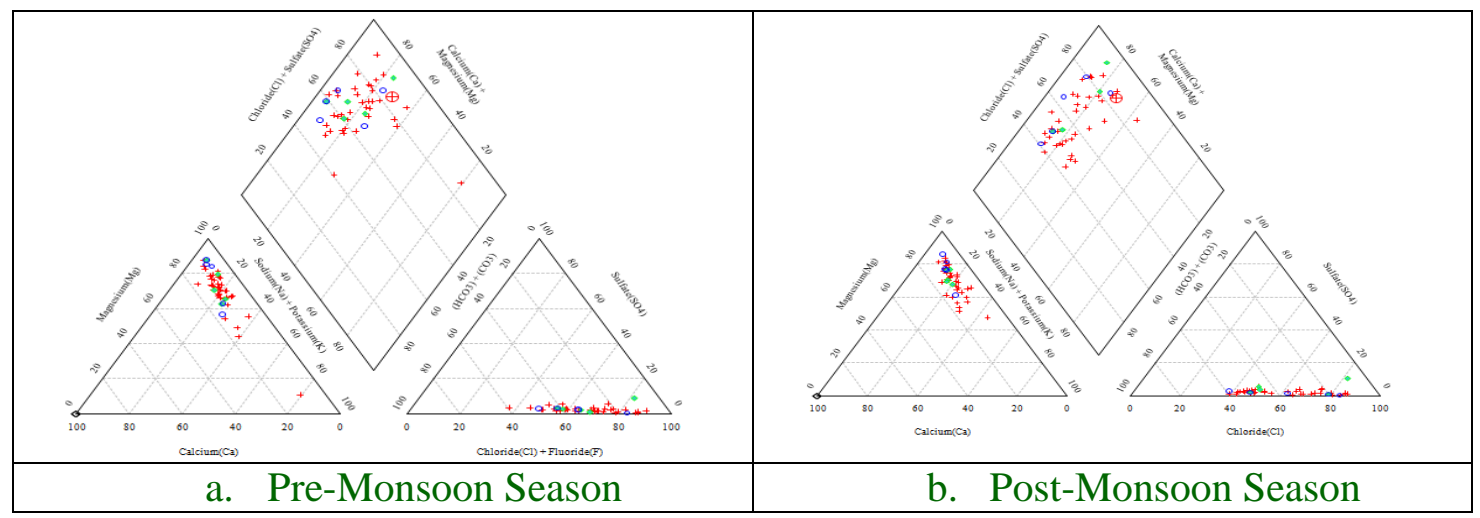

Fig.6 Piper Trilinear diagram (a. pre-monsoon; b. post-monsoon)

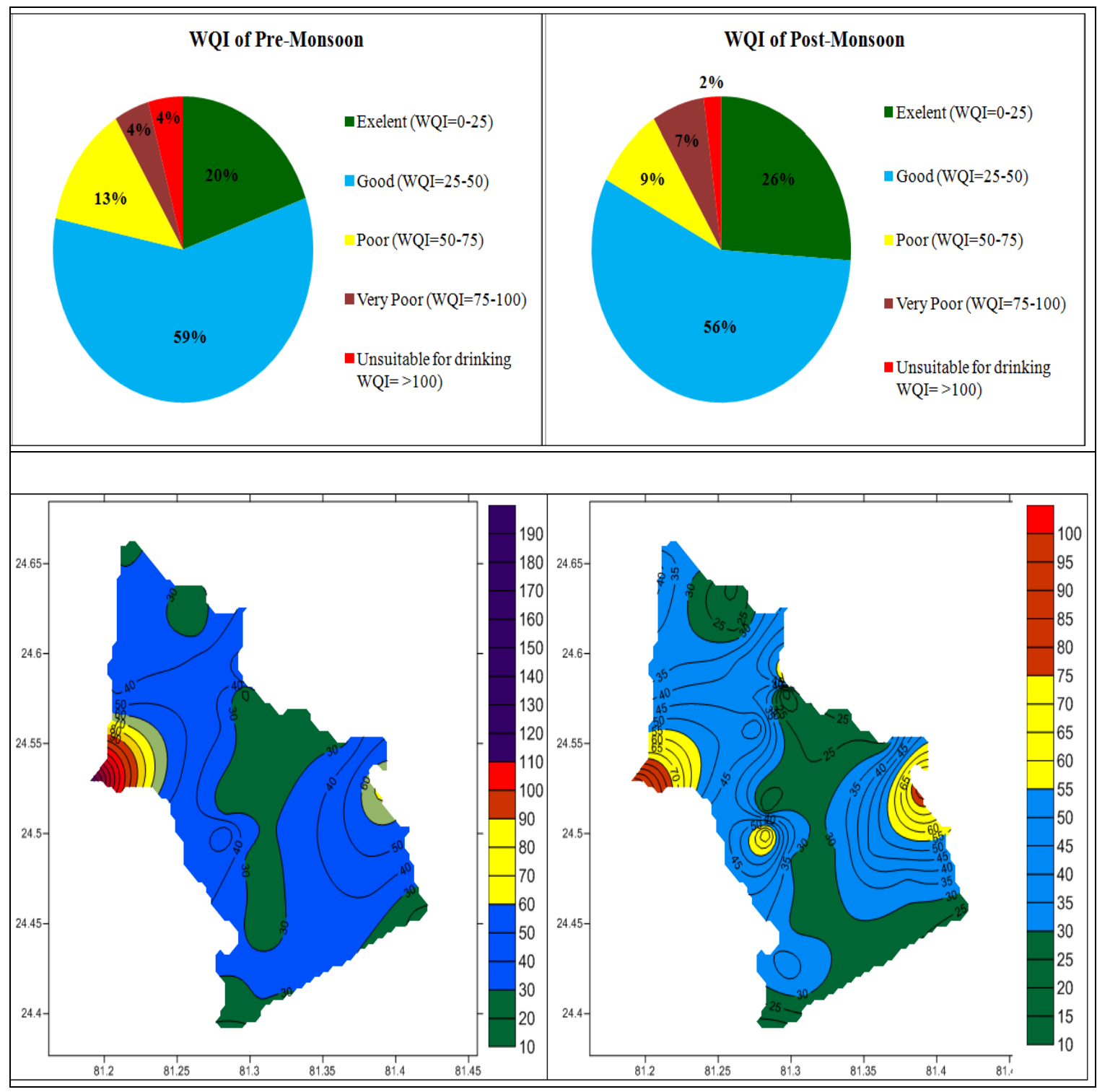

Fig.7 Categorization of groundwater WQI (a. pre-monsoon; b. post-monsoon) 


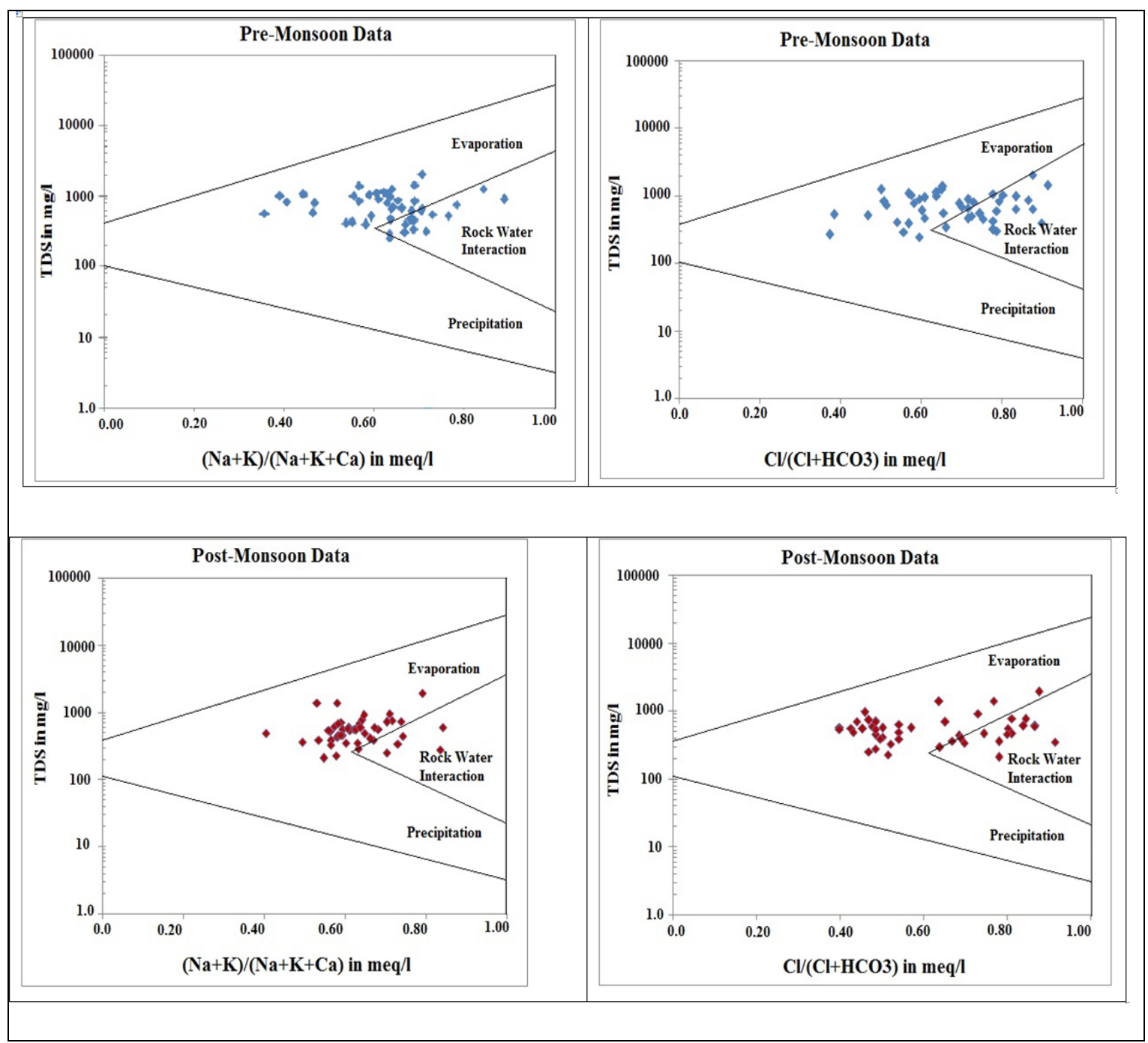

Fig.8 Gibb's Diagrams (a) pre-monsoon and (b) post-monsoon season

The rock-water interaction dominance field indicates the interaction between rock chemistry and the chemistry of the percolated waters under the subsurface. Dissolution and displacement reactions in rocks lining the aquifers are primary reasons behind changing concentrations of major ions in solution.

It is observed that some parameters exceed the standard limits. The ground water is hard to very hard in nature. The overall study reveals that water concentration of various cations and anions suggest that the groundwater of the area is partially suitable for drinking purpose. To overall irrigation water quality of the samples collected, some computed water quality parameters have been considered. The analysis of various parameters like EC, sodium percentage, integrated sodium adsorption ratio (SAR), Soluble Sodium Percentage (SSP), Permeability Index (PI) and Residual Sodium Carbonate (RSC) suggest that ground water of the area is suitable for irrigation purpose.

\section{References}

Ackah M., Agyermang O, Anim A. K. et al., (2011). Assessment of groundwater quality for drinking and irrigation: the case study of Teeiman-Oyarifa community, Ga East Municipality, 
Ghana. Proceedings of International Academy of Ecology and Environmental Sciences, 1 (3-4): 186-194.

Bartram J., and Balance, R. (1996). Water quality monitoring - a practical guide to the design and implementation of freshwater quality studies and monitoring programme. Int.J.Curr.Microbiol.App.Sci (2018) 7(1): 2381-2386 2386 Geneva: UNEP and WHO.

Bhargawa G. P. (2003). Training material for undertaking studied on genesis of sodic / alkali soils. Division of soil and crop management, ICAR-central soil salinity research institute Karnal-132001.

Cui, Y.J., Y.G. Zhu, R.H. Zhai, D.Y. Chen, Y.Z. Huang, Y. Qui and J.Z. Liang. 2004. Transfer of metals from near a smelter in Nanning, China. Environmental International 30: 785-791.

Davis S.N. and Dewiest R.J. (1966). Hydrogeology, Wiley, New York.

Dixit, A., and Shrivastava S. (2013). Assessment of Parameters of Water Quality Analysis of Hanumantal and

Doneen LD (1964) Water quality for agriculture. Department of irrigation, University of California. Davis. pp. 48.

Dwivedi Arvind, Dwivedi H. P. and Tiwari Sachchidanand (2017). Quality Analysis of Hydrosphear Water of Deosar Block in District Singrauli, Madhy Pradesh,India. Intrnational Journal of Advanced Research in Chemical Science. Vol 4, pp. 22-26. ISSN 2349-039X, http://dx.doi.org/10.20431/2349-0401003, www.arcjournals. Org.

Eatson E.M. (1950). Significance of carbonate in irrigation water, Soil. Sci., 69:123-133.

Eriyamremu, G.E., Asagba S.O., Akpoborie A. and Ojeaburu S.I. (2005). Evaluation of lead and cadmium levels in some commonly consumed vegetables in the Niger-Delta oil area of Nigeria. Bulletin of Environmental Contamination and Toxicology 75: 278-283.

Gibbs RJ (1970) Mechanisms Controlling World's Water Chemistry. Science 170: 1088-1090.
Gupta SK, Gupta, IC (1987). Management of Saline Soils and Water. Oxford and IBH Publ. Co., New Delhi, India, 399p.

Hegde, G.V. (2006). Evaluation of chemical quality of groundwater in Dharwad District, Karnataka, Jour. Geol. Soc. India v.67 pp.47-58.

Hirsch R.M., Alexander ,R.B. and Smith R.A., (1991). Selection of methods for the detection and estimation of trends in water quality, Water resources research, 27(5), 803-813

Kelly W.P. (1940). Permissible composition and concentration of irrigated waters. In: Proceedings of the ASCF66. p. 607.

Kumar A., (2004). Water Pollution. Nisha Enterprises, New Delhi.

Marshall, F.M., J. Holden, C. Ghose, B. Chisala, E. Kapungwe, J. Volk, M. Agrawal, R. Agrawal, R.K. Sharma and R.P. Singh (2007). Contaminated Irrigation Water and Food Safety for the Urban and Periurban Poor: Appropriate Measures for Monitoring and Control from Field Research in India and Zambia. Inspection Report DFID Enkar R8160, SPRU, University of Sussex. www.pollutionandfood. net 2007.

Mishra Shankar Prasad, Shukla ARUN kumar (2016). Assessment of Ground Water Quality of Semariya Area District, Madhya Pradesh, India. Inter. Jour. Of chen Tech research. Vol. 9, pp. 302-307.

Mishra, U.K. (2010). Hydrogeological studies of Sirmour Area, Rewa District, Madhya Pradesh. Unpublish Ph- D, Thesis, A.P.S. University Rewa, 174p.

Mishra, U.K., Tripathi, A.K., Tiwari Saras and Mishra Ajay (2012). Assessment of Quality and pollution potential groundwater around Dabhaura area, Rewa Districts Madhya Pradesh India, Earth Science Research, 1(2): 249-261.

Muchuweti, M., J.W. Birkett, E. Chinyanga, R. Zvauya, Scrimshaw M.D. and Lester J.N. (2006). Heavy metal content of vegetables irrigated with mixture of waste water and sewage sludge in Zimbabwe: implications for human health. 
Agriculture, Ecosystem and Environment 112: 41-48.

Pandian, K. and Sankar, K. (2007). Hydrochemistry and groundwater quality in the Vaippar river basin, Tamil Nadu. Jour. Geol. Soc. India, v.69, pp. 970-982.

Piper A.M. (1994). A graphic procedure in the geochemical interpretation of water analysis. Am Geophys Union Trans 25: 914-923.

Pophare, A. M. and Dewalkar, M. S. (2007). Groundwater quality in Eastern and Southeastern parts of Rajura Tehsil, Chandrapur District, Maharastra. Gond. Geol. Magz. Spec. Vol. pp.119-126.

Purushottam, D., Narsing Rao, A., Ravi Prakash, M., Ahmed, S. and Babu, A.G. (2011). Environmental impact on groundwater of Maheshwaram watershed, Ranga Reddy District, Andhra Pradesh. J. Geol. Soc. India, 77(6), 539-548.

Ragunath H. M. (1987). Ground Wter $\left(2^{\text {nd }}\right.$ addition). Wiley Eastern Ltd., New Delhi, India.

Richards L.A. (1954). Diagnosis and Improvement of Saline Alkali Soils: Agriculture, Vol.160. Handbook 60, US Department of Agriculture, Washington DC.

Sayyed M.R.G, Wagh G.S. (2011). An assessment of groundwater quality for agricultural use: a case study from solid waste disposal site SE of Pune, India. Proceedings of the International Academy of Ecology and Environmental Sciences, 1(3-4): 195-201.

Sayyed M.R.G., Sayadi M.H. (2011). Variations in the heavy metal accumulations within the surface soils from the Chitgar industrial area Tehran. Proceedings of the
International Academy of Ecology and Environmental Sciences, 1(1): 36-46.

Singh A.K. (2002). Quality Assessment of surface and subsurface water of Damodar river basin, Indian Journal of Environmental Health, 44(1):41-49.

Tiwari Priyanka (2017). Water quality assessment for drinking and irrigation purpose. Indian Journal Science Research ISSN: 0976-2876, 13 (2): 140-142, 2017

Tiwari, R.N., Bharti, S.L., Mishra, Umesh (2010). Hydrogeochemical Studies of Groundwater from Odda River Basin, Rewa District, Madhya Pradesh, Gondwana Geological Magazine, Special v. No. 12, pp.85-93.

Tiwari, R.N., Dubey, D.P. and Bharti, S.L. (2009). Hydrogeochemistry and groundwater quality in Beehar River Basin, Rewa district, Madhya Pradesh, Inr. Jour. Earth Eng. Sci., v.2(4), pp. 324330.

Todd D. (1980). Groundwater Hydrology, 2nd ed. John Wiley and Sons. New York, 282300.

Tripathi A.K., Mishra U.K., Ajay Mishra and Parul Dubey (2012). Assessment of Groundwater Quality Gurh Tehseel, Rewa District, Madhya Pradesh, India. International Journal of Scientific \& Engineering Research Volume 3, Issue 9, September-2012 1.

Wilcox L.V. (1955). Classification and use of irrigation waters. USDA, Circular 969, Washington.

Zhang W.J. Jiang F.B., Ou J.F. (2011). Global pesticide consumption and pollution: with China as a focus. Proceedings of the International Academy of Ecology and Environmental Sciences, 1(2): 125-144.

\section{How to cite this article:}

Satish Kumar Singh, S. K. Tripathi, K. P. Mishra, A. K. Pandya and Awasthi, M. K. 2020. Water Quality Assessment for Drinking and Irrigation Purpose of Rewa Block, District-Rewa, Madhya Pradesh, India. Int.J.Curr.Microbiol.App.Sci. 9(04): 2576-2589. doi: https://doi.org/10.20546/ijcmas.2020.904.309 